\title{
BEHAVIORAL REACTIONS AND COGNITIVE FUNCTIONS IN RATS WITH VASCULAR MODEL OF ALZHEIMER'S TYPE DEMENTIA AT DIFFERENT STAGES OF DISEASE BEFORE AND AFTER STEM CELL CORRECTION
}

\author{
Lukyanova Y., Nikolaeva O., Pavlova O., Vasyleva I., \\ Naglov O., Shchegelskaya E., Omelchenko E. \\ Kharkiv National Medical University, V.N.Karazin Kharkiv National University, \\ Kharkiv medical academy of postgraduate education
}

https://doi.org/10.35339/ic.7.3.118-124

\begin{abstract}
Background. The recent investigations offer to conduct the study of Alzheimer disease (AD) mechanisms using diverse experimental models. However, behavioral and cognitive impairment in rats at the different stages of vascular model of dementia of Alzheimer's type developed by us has not been investigated. Subjects and methods. The experiment was performed on 32 male WAG rats weighing 180-250 g which were divided into 4 groups. Rats from group 1 and 3 were injected aqueous solution of sodium nitrite at a dose of $50 \mathrm{mg} / \mathrm{kg}$ of body mass intraperitoneally during 14 and 28 days respectively. Groups 2 and 4 received 500,000 mesenchymal stem cells in suspension intravenously against a background of experimental nitrite-induced $\mathrm{AD}$. To estimate the behavioral reactions and cognitive functions the Open Field Test (OFT) and Passive Avoidance test (PAT) were used. Results. In all experimental groups in most cases significant decrease in vertical and horizontal activity $(\mathrm{p}<0.05)$ and an increase in the number of defecation in the OFT were found. Rats from group 3 had the drop in locomotor, research and orientation activity. In the OFT and PAT in groups 2, 4 improvement in research activity and significant cognitive functions recovery was observed $(\mathrm{p}=0.012)$ after stem cell correction. Conclusion. Progression of the protective inhibition and cognitive impairment was found during the experiment. Stem cell administration had positive effects on brain function recovery.
\end{abstract}

Key words: Alzheimer disease, sodium nitrite, stem cells, cognition, behavior, brain, rats.

\section{Introduction}

According to the World Health Organization (2019) around 50 million people have dementia worldwide with nearly 10 million new cases every year. Alzheimer disease (AD) is the most common form of dementia and may contribute to $60-70 \%$ of cases [1]. Incremental increase of dementia of Alzheimer's type leads to researching the mechanisms of the disease onset and progression. The main amyloid cascade hypothesis involves the excessive production of amyloid plaques with their subsequent accumulation and future nerve cells apoptosis [2]. It is obvious that this theory

Corresponding Author:

Lukyanova Yevgeniya M., PhD student.

Department of Physiological Pathology,

Kharkiv National Medical University, Ukraine,

E-mail: zeekmail@ukr.net cannot alone exactly elaborate the all steps of neurodegeneration. The scientists propose other supplemental pathways of progressive neurons injury and loss. It is well known that oxidative stress, neuroinflammation cause endothelial dysfunction that could play the crucial role in development neurodegeneration [3].

The recent investigations offer to conduct the study of AD mechanisms using diverse experimental models. There are plenty of transgenic and non-transgenic animal AD models in vivo and in vitro tissue, cell, molecular simulation models [4]. One of the most common psychopharmacological model of Alzheimer's type dementia is induced by scopolamine. It was published that the activity of choline acetyltransferase was dropped in the cortex of AD patients [5]. It was associated with brain lesions and clinical performance [6;7]. The cholinergic 
hypothesis of $\mathrm{AD}$ was accepted and chronic administration of scopolamine during 28 days was allowed for further AD researching [8; 9].

We have developed another model of dementia of Alzheimer's type where the endothelial dysfunction triggered amyloid formation and cognitive impairment. This model caused by chronic administration of aqueous solution of sodium nitrite intraperitoneal at dose at $50 \mathrm{mg} / \mathrm{kg}$ of body mass during 2 weeks [10]. It was not investigated the behavioral and cognitive impairment at the different stages of disease and after stem cells injections.

\section{Purpose, subjects and methods}

\subsection{Purpose}

The aim of our study was to assess the changes of behavioral reactions and cognitive functions in rats with vascular model of Alzheimer's type dementia at the different stages of disease before and after stem cells administration.

\subsection{Subjects \& Methods}

The experiment was performed on 32 male WAG rats weighing 180-250 $\mathrm{g}$ which were divided into 4 groups. Rats from group 1 (sodium nitrite 2 weeks, $n=8$ ) and group 3 (sodium nitrite 4 weeks, $\mathrm{n}=8$ ) were injected aqueous solution of sodium nitrite at a dose of $50 \mathrm{mg} / \mathrm{kg}$ of body mass intraperitoneally during 14 and 28 days ( 2 and 4 weeks), respectively, resulted in the development of dementia of Alzheimer's type of vascular genesis. Group 2 (sodium nitrite 2 weeks + stem cells, $\mathrm{n}=8$ ) and group 4 (sodium nitrite 4 weeks + stem cells, $n=8$ ) received 500,000 mesenchymal stem cells (MSCs) in suspension intravenously against a background of experimental nitriteinduced $\mathrm{AD}$.

All institutional and national guidelines for the care and use of laboratory animals were strictly followed. The Ethics and Bioethics Commission of Kharkiv National Medical University (October 10, 2018, minutes of the meeting №8) confirmed that the design and manipulations during this experiment were compliant to bioethical requirements of $\mathrm{EU}$ Directive 2010/63/EU on the protection of animals used for scientific purposes and the Council of Europe Convection for the Protection of Vertebrate Animals used for Experimental and other Scientific Purposes (ETS123).

Open Field test (OFT) was used to characterize behavioral reactions such as locomotion, anxiety, neophilia (ability to adapt rapidly to extreme change) and exploration. Our OFT apparatus had a circle area with holes into the walls and the field marked with a grid and square crossings. The main variables recorded during the next 300 sec were: crossings (number of times the line of a square is crossed with all 4 legs), head dipping (number of putting rat's head into the hole), rearings (number of times the animal stands on its hind legs), grooming (frequency of grooming activity), number of defecation [11-13]. The animals were tested in the beginning of experiment before sodium nitrite injections, just after sodium nitrite injections and before stem cells injections and in 2 weeks after sodium nitrite and stem cells injections

Cognitive functions were evaluated using Passive Avoidance Test (PAT). In PAT formation of the conditioned reflex was fixed during $180 \mathrm{sec}$. If animal crossed from the light to the dark compartment with mild foot shock next day after training, the passive avoidance response or conditioned reflex was not formed (0). If rat avoids the entry to the dark compartment and stays at the light compartment the passive avoidance response is formed (1) [14; 15].

Primary culture of MSCs was obtained from bone marrow cell suspension flushed out of rat femurs. The cells were washed in Hanks' balanced salt solution, centrifuged at $450 \mathrm{~g}$ for $10 \mathrm{~min}$ and plated in $75 \mathrm{~cm}^{2}$ culture flasks at a density of $4 \times 105$ cells $/ \mathrm{cm}^{2}$ in DMEM/F12 (1/1) containing 2mM L-glutamine, 10\% FBS (SIGMA-ALDRICH, cat.n. F7524) and $2 \mu 1 / \mathrm{ml}$, Antibiotic Antimycotic Solution (SIGMA-ALDRICH, cat.n. A5955). The medium with nonadherent cells was discarded after 24 hours of the culture and fresh medium was added to the adherent fibroblast-like MS cells. They were cultured at 37 ? $\mathrm{C}$ and $5 \% \mathrm{CO} 2$ in air in an $\mathrm{CO} 2$ - incubator for 14 days in the medium changed every 3 days. All reagents for culture were purchased from SIGMAALDRICH [16].

To evaluate the behavioral reaction changes inside each group during different periods (before sodium nitrite injections, just after sodium nitrite injections and before stem cells injections, 2 weeks after sodium nitrite injections) one-way ANOVA test was used. To estimate the stem cells efficiency on cognitive functions Pearson's chisquared test was used. If $p$ values were below 0.05 , the difference was statistically significant. All numerical data were analyzed using IBM SSPS Statistics.

\section{Conflict of interests}

The authors of the article declare no conflict of interest.

\section{Results \& Discussion}

Analyzing the behavioral reactions during oneway analysis of variance the Levene's test 
showed a large dispersion of data with identical variation of samples in group 1 (significant point $>0.05$ ), which indicates a single adherence to the conditions of the experiment. Throughout the experiment, there was a significant decrease in the number of head dipping into the holes by almost 3 times, which indicates a decrease in research activity. A significant increase in the number of defecations by almost 3 times confirms an increase in anxiety in rats $(p<0.05)$. An insignificant decline in the number of rearings and grooming is a nonspecific manifestation of a decrease in orientationalresearch activity, which correlates with a decrease in number of head dipping into the holes.
[Poshivalov, V. P. (1978). Jetiologicheskij atlas dlja farmakologicheskih issledovanij na laboratornyh gryzunah. Moscow.]. At the same time, there is a decrease in locomotive activity, which is accompanied by an insignificant decrease in the number of crossings (Table 1).

Rats from group 2 showed a significant decrease in locomotion. Comparing the number of head dipping into the holes at different periods of time the explorative activity in 2 weeks after the stem cells administration was less expressed than before the experiment, but higher than before the stem cells correction. It can be assumed that the recovery of explorative activity in animals is

Open Field Test (OFT) behavioral reaction results in group 1 (sodium nitrite 2 weeks)

\begin{tabular}{|c|c|c|c|c|c|c|}
\hline $\begin{array}{l}\text { Behavior } \\
\text { reactions }\end{array}$ & Period of time & $\begin{array}{c}\text { Mean } \pm \mathrm{Cl} \\
\text { (confidence interval) }\end{array}$ & $\begin{array}{l}\text { SD (standart } \\
\text { deviation) }\end{array}$ & $\begin{array}{l}\text { Levene's } \\
\text { test }\end{array}$ & $\begin{array}{c}\text { Significant } \\
\text { point }\end{array}$ & $\begin{array}{l}\text { ANOVA, } \\
\text { p-value }\end{array}$ \\
\hline \multirow[t]{3}{*}{ crossing } & $\begin{array}{l}\text { before sodium } \\
\text { nitrite injection }\end{array}$ & $36.69 \pm 9.85$ & 16.31 & \multirow{3}{*}{0.069} & \multirow{3}{*}{0.934} & \multirow{3}{*}{0.622} \\
\hline & $\begin{array}{l}\text { after sodium } \\
\text { nitrite injection }\end{array}$ & $38.46 \pm 9.69$ & 16.03 & & & \\
\hline & $\begin{array}{l}\text { in } 2 \text { weeks after } \\
\text { sodium nitrite } \\
\text { injection }\end{array}$ & $29.5 \pm 22.52$ & 14.15 & & & \\
\hline \multirow[t]{3}{*}{\begin{tabular}{|l|} 
head dipping \\
into the holes \\
\end{tabular}} & $\begin{array}{l}\text { before sodium } \\
\text { nitrite injection }\end{array}$ & $3.85 \pm 1.15$ & 1.91 & \multirow{3}{*}{1.931} & \multirow{3}{*}{0.165} & \multirow{3}{*}{0.044} \\
\hline & $\begin{array}{l}\text { after sodium } \\
\text { nitrite injection }\end{array}$ & $1,85 \pm 1,63$ & 2,70 & & & \\
\hline & $\begin{array}{l}\text { in } 2 \text { weeks after } \\
\text { sodium nitrite } \\
\text { injection }\end{array}$ & $1,25 \pm 1,52$ & 0,96 & & & \\
\hline \multirow[t]{3}{*}{ rearing } & $\begin{array}{l}\text { before sodium } \\
\text { nitrite injection }\end{array}$ & $2.5 \pm 1.95$ & 2.33 & \multirow{3}{*}{2.993} & \multirow{3}{*}{0.077} & \multirow{3}{*}{0.059} \\
\hline & $\begin{array}{l}\text { after sodium } \\
\text { nitrite injection }\end{array}$ & $5.63 \pm 3.09$ & 3.7 & & & \\
\hline & $\begin{array}{l}\text { in } 2 \text { weeks after } \\
\text { sodium nitrite } \\
\text { injection }\end{array}$ & $1.75 \pm 2.72$ & 1.71 & & & \\
\hline \multirow[t]{3}{*}{ defecations } & $\begin{array}{l}\text { before sodium } \\
\text { nitrite injection }\end{array}$ & $1 \pm 0.74$ & 1.22 & \multirow{3}{*}{0.212} & \multirow{3}{*}{0.81} & \multirow{3}{*}{0.019} \\
\hline & $\begin{array}{l}\text { after sodium } \\
\text { nitrite injection }\end{array}$ & $0.92 \pm 0.94$ & 1.55 & & & \\
\hline & $\begin{array}{l}\text { in } 2 \text { weeks after } \\
\text { sodium nitrite } \\
\text { injection }\end{array}$ & $3.25 \pm 2.39$ & 1.5 & & & \\
\hline \multirow[t]{3}{*}{ grooming } & $\begin{array}{l}\text { before sodium } \\
\text { nitrite injection }\end{array}$ & $0.69 \pm 0.57$ & 0.95 & \multirow{3}{*}{3.345} & \multirow{3}{*}{0.05} & \multirow{3}{*}{0.332} \\
\hline & $\begin{array}{l}\text { after sodium } \\
\text { nitrite injection }\end{array}$ & $0.69 \pm 0.57$ & 0.95 & & & \\
\hline & $\begin{array}{l}\text { in } 2 \text { weeks after } \\
\text { sodium nitrite } \\
\text { injection }\end{array}$ & 0 & 0 & & & \\
\hline
\end{tabular}

Values are mean \pm confidence interval (CI) for the mean.

Variances for each group do not statistically significantly differ. ANOVA results may be considered correct (Levene's test, significant point $>0,05$ ).

The influence of time on behavior results is statistically significant (ANOVA, $p$-value $<0,05$ ). 
associated with the effect of stem cells. Reducing the number of defecations and the number of crossings hypothesizes the animal stress becomes less. However, according to Kaluev A.V. (2002), Markel "A.L. (1981), this type of reaction signifies the development of defensive inhibition in response to stress factors (pain factor resulting from injections and open field testing) (Table 2).

In rats from group 3 there was a drop in all indicators against a background of the increase in the number of defecation (an increase in anxiety levels). found. Thus, the decrease in horizontal and vertical locomotion in contrast to increased anxiety level is not corrected by stem cells. It is possible that protective inhibition in this case is due not only to the administration of sodium nitrite, but also to chronic pain stress (Table 4).

The variances of all results of behavioral reactions in control group were not significantly different.

During PAT conditional reflex was formed in $81.25 \%$ of cases in rats from group 2,4 who received

OFT behavioral reaction results in group 2 (sodium nitrite 2 weeks + stem cells)

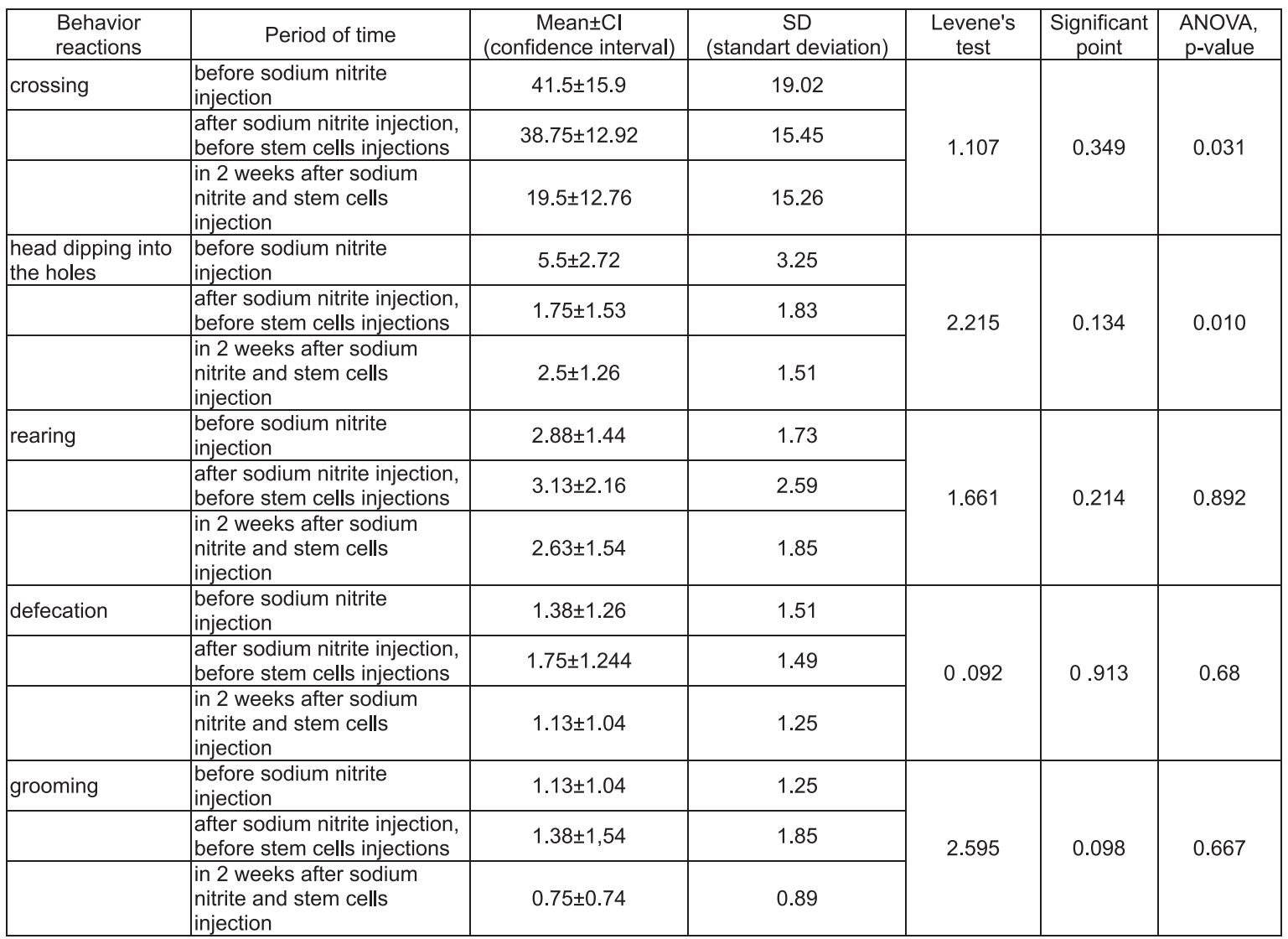

Values are mean \pm confidence interval (CI) for the mean.

Variances for each group do not statistically significantly differ. ANOVA results may be considered correct (Levene's test, significant point $>0,05$ ).

The influence of time on behavior results is statistically significant (ANOVA, p-value $<0,05$ ).

Conspicuous is the fact that the number of crossings and head dipping into the holes with heterogeneous data variance are reduced by 4 and 11 times respectively $(\mathrm{p}<0.001)$. It is probably associated with large damage of brain tissue (Table 3).

In rats from group 42 weeks after stem cells injection insignificant raise of the number of head dipping into the holes groups compared to period of time after finishing of sodium nitrite administration and before stem cells injection was stem cells. While in group 1,3 the conditional reflex was not formed in $37.5 \%$ of cases. These results demonstrate positive effects of stem cells on cognitive recovery in rats (Table 5).

\section{Conclusion}

1. In all experimental groups with chronic stress caused by prolonged intraperitoneal administration of aqueous solution of sodium nitrite and single intravenous administration of stem cells suspension, protective inhibition develops. It is 
Table 3

OFT behavioral reaction results in group 3 (sodium nitrite 4 weeks)

\begin{tabular}{|c|c|c|c|c|c|c|}
\hline $\begin{array}{c}\text { Behavioral } \\
\text { reactions }\end{array}$ & $\begin{array}{l}\text { Period } \\
\text { of time }\end{array}$ & $\begin{array}{c}\text { Mean } \pm \mathrm{Cl} \\
\text { (confidence interval) }\end{array}$ & $\begin{array}{c}\mathrm{SD} \\
\text { (standart deviation) }\end{array}$ & $\begin{array}{c}\text { Levene's } \\
\text { test }\end{array}$ & $\begin{array}{c}\text { Significant } \\
\text { point }\end{array}$ & $\begin{array}{l}\text { ANOVA, } \\
\text { p-value }\end{array}$ \\
\hline crossing & $\begin{array}{l}\text { before sodium nitrite } \\
\text { injection }\end{array}$ & $40.71 \pm 10.23$ & 11.06 & \multirow{3}{*}{6.783} & \multirow{3}{*}{0.006} & \multirow{3}{*}{0.000} \\
\hline & $\begin{array}{l}\text { after sodium nitrite } \\
\text { injection }\end{array}$ & $19.71 \pm 15.22$ & 16.46 & & & \\
\hline & $\begin{array}{l}\text { in } 2 \text { weeks after sodium } \\
\text { nitrite injection }\end{array}$ & $10.43 \pm 4.1$ & 4.43 & & & \\
\hline \multirow[t]{3}{*}{$\begin{array}{l}\text { head dipping into } \\
\text { the holes }\end{array}$} & $\begin{array}{l}\text { before sodium nitrite } \\
\text { injection }\end{array}$ & $4.86 \pm 2.23$ & 3.06 & \multirow{3}{*}{5.166} & \multirow{3}{*}{0.017} & \multirow{3}{*}{0.000} \\
\hline & $\begin{array}{l}\text { after sodium nitrite } \\
\text { injection }\end{array}$ & $0.71 \pm 0.88$ & 2.41 & & & \\
\hline & $\begin{array}{l}\text { in } 2 \text { weeks after sodium } \\
\text { nitrite injection }\end{array}$ & $0.43 \pm 0.49$ & 0.95 & & & \\
\hline \multirow[t]{3}{*}{ rearing } & $\begin{array}{l}\text { before sodium nitrite } \\
\text { injection }\end{array}$ & $4.29 \pm 3.45$ & 3.73 & \multirow{3}{*}{4.825} & \multirow{3}{*}{0.021} & \multirow{3}{*}{0.006} \\
\hline & $\begin{array}{l}\text { after sodium nitrite } \\
\text { injection }\end{array}$ & $0.43 \pm 0.49$ & 0.53 & & & \\
\hline & $\begin{array}{l}\text { in } 2 \text { weeks after sodium } \\
\text { nitrite injection }\end{array}$ & $0.57 \pm 0.73$ & 0.79 & & & \\
\hline \multirow[t]{3}{*}{ defecation } & $\begin{array}{l}\text { before sodium nitrite } \\
\text { injection }\end{array}$ & $0.57 \pm 0.73$ & 0.79 & \multirow{3}{*}{2.482} & \multirow{3}{*}{0.112} & \multirow{3}{*}{0.362} \\
\hline & $\begin{array}{l}\text { after sodium nitrite } \\
\text { injection }\end{array}$ & $0.86 \pm 1.35$ & 1.46 & & & \\
\hline & $\begin{array}{l}\text { in } 2 \text { weeks after sodium } \\
\text { nitrite injection }\end{array}$ & $1.43 \pm 0.9$ & 0.98 & & & \\
\hline \multirow[t]{3}{*}{ grooming } & $\begin{array}{l}\text { before sodium nitrite } \\
\text { injection }\end{array}$ & $2.83 \pm 3.75$ & 2.48 & \multirow{3}{*}{4.507} & \multirow{3}{*}{0.026} & \multirow{3}{*}{0.335} \\
\hline & $\begin{array}{l}\text { after sodium nitrite } \\
\text { injection }\end{array}$ & $2 \pm 0.73$ & 2 & & & \\
\hline & $\begin{array}{l}\text { in } 2 \text { weeks after sodium } \\
\text { nitrite injection }\end{array}$ & 0 & 0 & & & \\
\hline
\end{tabular}

Values are mean \pm confidence interval (CI) for the mean.

Variances for each group do not statistically significantly differ. ANOVA results may be considered correct (Levene's test, significant point $>0,05$ ).

The influence of time on behavior results is statistically significant (ANOVA, p-value $<0.05$ ).

OFT behavioral reaction results in group 4 (sodium nitrite 4 weeks + stem cells)

Table 4

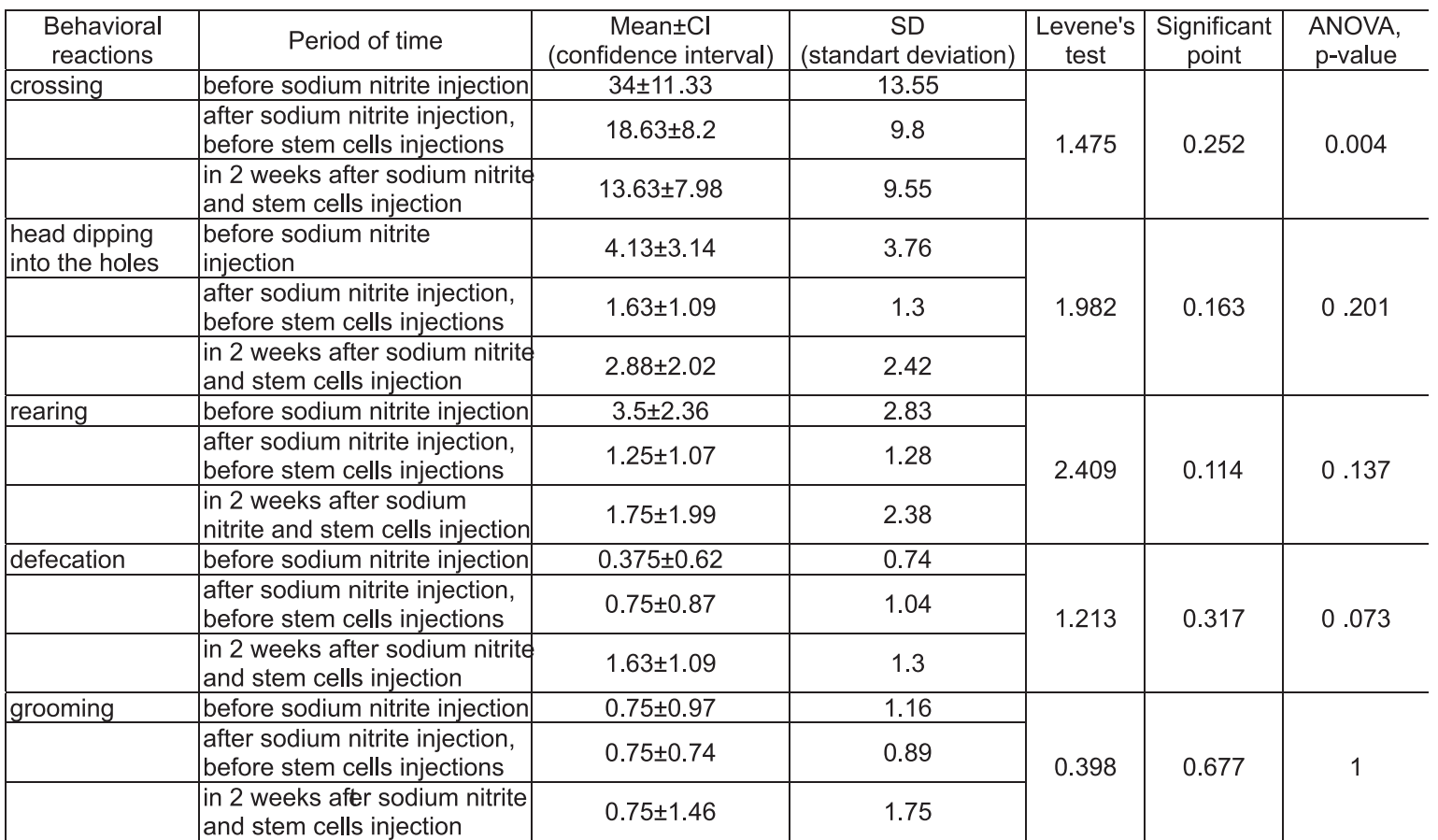

Values are mean \pm confidence interval (CI) for the mean.

Variances for each group do not statistically significantly differ. ANOVA results may be considered correct (Levene's test, significant point $>0,05$ ).

The influence of time on behavior results is statistically significant (ANOVA, $p$-value $<0.05$ ). 
Table 5

Passive Avoidance Test (PAT): cognitive function comparison between group with stem cell injections (group 2+group 4) and group without stem cells injections (group 1+group 3)

\begin{tabular}{|l|c|c|c|}
\hline \multicolumn{1}{|c|}{ Test } & $\begin{array}{c}\text { Sodium nitrite 1, 3 weeks } \\
\text { groups without stem cells }\end{array}$ & $\begin{array}{c}\text { Sodium nitrite 2, 4 weeks } \\
\text { groups with stem cells }\end{array}$ & Altogether \\
\hline Failed & 10 & 3 & 13 \\
\hline Passed & 6 & 13 & 19 \\
\hline Altogether & 16 & 16 & 32 \\
\hline
\end{tabular}

Actual and expected results are statistically different. (Pearson's chi-squared test, $\mathrm{p}=0.012(<0.05)$.

accompanied by decrease in vertical and horizontal activity and increase in the number of defecation, as determined by testing in the open field.

2. In all rats with a 4-week disease model, the drop in locomotor, research and orientation activity was found. Probably, it means that the brain tissue is damaged significantly.
3. In the OFT in all animal from groups 2,4 improvement in research activity in comparison with that before stem cells introduction was observed.

4. In the PAT higher percentage of rats from groups 2, 4 passed this test which indicates the significant cognitive functions recovery after stem cell correction.

\section{References}

1. Dementia. (2019, September 19). Retrieved from https://www.who.int/news-room/fact-sheets/ detail/dementia

2. Hardy, J., \& Higgins, G. (1992). Alzheimer's disease: The amyloid cascade hypothesis. Science, 256(5054), 184-185. doi:10.1126/science. 1566067

3. Carvalho, C., \& Moreira, P. I. (2018). Oxidative Stress: A Major Player in Cerebrovascular Alterations Associated to Neurodegenerative Events. Frontiers in Physiology, 9. doi:10.3389/fphys.2018.00806

4. Li, X., Bao, X., \& Wang, R. (2015). Experimental models of Alzheimer's disease for deciphering the pathogenesis and therapeutic screening (Review). International Journal of Molecular Medicine, 37(2), 271-283. doi:10.3892/ijmm.2015.2428

5. Perry, E., Perry, R., Blessed, G., \& Tomlinson, B. (1977). Necropsy Evidence Of Central Cholinergic Deficits In Senile Dementia. The Lancet, 309 (8004), 189. doi:10.1016/s0140-6736(77)91780-9

6. Perry, E. K., Tomlinson, B. E., Blessed, G., Bergmann, K., Gibson, P. H., \& Perry, R. H. (1978). Correlation of cholinergic abnormalities with senile plaques and mental test scores in senile dementia. BMJ, 2(6150), 1457-1459. doi:10.1136/bmj.2.6150.1457

7. Mountjoy, C. Q., Rossor, M. N., Iversen, L. L., \& Roth, M. (1984). Correlation Of Cortical Cholinergic And Gaba Deficits With Quantitative Neuropathological Findings In Senile Dementia. Brain, 107(2), 507-518. doi:10.1093/brain/107.2.507

8. Flood, J. F., \& Gherkin, A. (1987). Scopolamine effects on memory retention in mice. Alzheimer Disease \& Associated Disorders, 1 (1), 48. doi:10.1097/00002093-198701000-00026

9. Gorbach, T. V., Nakonechna, O. A., Tkachenko, A. S., Shcholok, T. S., \& Onikova, A. O. (2018). Levels of Thyroid Hormones and Indices of Energy Metabolism in the Cerebral Cortex of Rats with Experimental Alzheimer's Disease. Neurophysiology, 50(3), 159-165. doi:10.1007/s11062-018-9732-4

10. Nikolaeva, O., Pavlova, O., Lukyanova, Y., Gubina-Vakulik, G., \& Gorbach, T. (2020). UA. Patent No. 141759. State Enterprise "Ukrainian Institute of Intellectual Property".

11. Walsh, R. N., \& Cummins, R. A. (1976). The open-field test: A critical review. Psychological Bulletin, 83(3), 482-504. doi:10.1037/0033-2909.83.3.482

12.Janicke, B., \& Coper, H. (1996). Tests in Rodents for Assessing Sensorimotor Performance During Aging. Changes in Sensory Motor Behavior in Aging Advances in Psychology, 201-233. doi:10.1016/ s0166-4115(96)80010-0

13. Samson A. L., Ju L., Kim H. A., Zhang S. R., Lee J. A., Sturgeon S. A., Schoenwaelder S. M. (2015). MouseMove: An open source program for semi-automated analysis of movement and cognitive testing in rodents. Scientific Reports, 5 (1). doi:10.1038/srep16171

14. Bondarenko, N. (2017). Anxiety and the Problem of "Inattentive" Animals in Water Maze Tests. The Russian Journal of Cognitive Science, 4 (4), 45-49. 
15. Eagle, A., Wang, H., \& Robison, A. (2016). Sensitive Assessment of Hippocampal Learning Using Temporally Dissociated Passive Avoidance Task. Bio-Protocol, 6 (11). doi:10.21769/bioprotoc.1821

16. Pyatikop, V., Jr, M. A., Shchegelskaya, E., Kutovoy, I., \&amp; Gubina-Vakulik, G. (2014). Migration features of labeled bone marrow mesenchymal stem cells in rats with modeled Parkinson-like syndrome. Ukrainian Neurosurgical Journal, 0(3), 42-48. doi:10.25305/unj.47491

17. Poshivalov, V. P. (1978). Jetiologicheskij atlas dlja farmakologicheskih issledovanij na laboratornyh gryzunah. Moscow.

18. Kaluev, A. V. (2002). Gruming i stress. Moscow: Aviks.

19. Markel', A. L. (1981). K ocenke osnovnyh harakteristik povedenija krys $\mathrm{v}$ teste otkrytogo polja. Zhurn. Vyssh. Nervn. Dejatel'nosti, 31(2), 301-307.

20.Povedencheskaja aktivnost' krys $\mathrm{v}$ "otkrytom pole" posle svetovoj ili temnovoj deprivacij i fizicheskogo pereutomlenija. (2016). Bjulleten' Sibirskoj Mediciny, 15 (3), 16-23. doi:10.20538/16820363-2016-3-16-23.

Received: 14-Jun-2020

Accepted: 06-Sep-2020 